\title{
Islamic Da'wah Values of Be'atan Tradition in Gorontalo City, Indonesia
}

\author{
Pattaling ${ }^{1}$, Said Subhan Posangi ${ }^{2}$, Tita Rostitawati ${ }^{3}$ \\ ${ }^{1}$ Department of Communication, State Islamic University of Sultan Amai Gorontalo, Indonesia \\ ${ }^{2}$ Faculty of Education and Teacher Training, State Islamic University of Sultan Amai Gorontalo, \\ Indonesia, email: saidsubhan70@iaingorontalo.ac.id \\ ${ }^{3}$ Department of Philosophy, State Islamic University of Sultan Amai Gorontalo, Indonesia
}

\author{
Article Info \\ Volume 8, Issue 1 \\ Page Number: 42-50 \\ Publication Issue : \\ January-February-2021
}

\section{Article History}

Accepted : 01 Jan 2021

Published : 11 Jan 2021

\section{ABSTRACT}

This study examined the Islamic $\mathrm{d} a$ 'wah values contained in the implementation of the be'atan tradition. The researchers collected data naturally through participant observation, in-depth interviews, documentation, and reference search. The researchers analyzed the data in a qualitative way. The data processing took place simultaneously with the data collection process through data reduction, data presentation, and data verification. The results showed that the implementation of the be'atan tradition contained Islamic $d a$ 'wah values. Those values of $d a$ 'wah are saying two sentences of shahadat and an explanation of the meaning they contain, an explanation of the pillars of Islam, the pillars of faith, and prayer to purify oneself. It also explains maintaining the good name of parents, moral education, self-purification, deepening of religious teachings, and the importance of being a pious child.

Keywords: Be'atan Tradition, Muslim Women, Islamic Da'wah, Gorontalo Culture

\section{INTRODUCTION}

Cultural discourse is inseparable from the diversity of humans in their community as a group of people who gather together on behalf of the nation, ethnicity, race, language, and religion in a specific area. As cultured creatures in their interactions, humans make culture an integral part of life and an effective means of self-expression. Whether we realize it or not, it becomes a strong and solid foundation in maintaining human survival. More specifically, as the basis for understanding human survival, culture is integrated from human nature from birth (Muhaimin et al.,
2005). Some of the explanations about this interpretation of fitrah, including those quoted by Professor Quraish Shihab from Ibn Asyur, that fitrah is a system manifested by Allah Almighty in every creature. The fitrah specific to the human type is what Allah Almighty created for him in relation to the body and mind (Shihab, 1996). In psychological terms, this potential of fitrah is referred to as the potential for heredity, which is the innate potential of humans that Allah Almighty has transmitted to His servants from generation to generation (Al-Baghdadiy, No Year). 
The great potential gifted by the creator to humans through the mind is evidence of how humans become superior beings - not denying the understanding based on God's revelation as a caliph on the earth and having the freedom to organize themselves, channel the creative abilities they use. to maintain their survival while formulating the norms that are used by each of them so as not to fall into a valley full of friction and collisions that can disrupt the management of life that has been designed in such away.

Human life cannot be separated from a culture because the parameter of a civilized human being is his ability to continue to exist and manage his life in a simple scope, starting from a simple family consisting of father, mother, and child. Meanwhile, at the community level, which is called the community, it has a protector that directs them to a goal they aspire to. One of the very obvious roles that the al-Qur'an describes towards humans in general and Muslims, in particular, is the obligation to carry out $d a^{\prime} w a h$, as instructed by the al-Qur'an, Al-Nahl: 125 .

"Call people to the way of your Lord with wisdom and good lessons and argue with them in a good way. Indeed, it is your Lord who knows better about who has strayed from His ways, and $\mathrm{He}$ who knows better those who are guided. "

The meaning and content of the above verse can be underlined that the form and process of preaching are divided into three things. First, wisdom means wisdom that is manifested in the form of a firm and correct words that can distinguish between rights and vanity (Soenarjo et al., No Year). Second, good advice, which means setting a good example, and it must be started in the person giving advice. Third, dialogue means conducting discussions using polite methods and methods based on the Prophet Muhammad's teachings. However, in actual implementation, there is an inequality between who has a share and the appropriate figure to carry out $d a$ 'wah activities, and the contribution of the mass media and print media in finding ideas as a basis for conception - which is both a means and a vehicle for conveying da'wah messages. Sometimes it has not found the right format to be used as a $d a$ 'wah concept, such as the practice of the tradition of profanity for children who have reached adulthood. If, in the end, the linkage of mass media and print media becomes the most effective means of conducting da'wah and fostering a relationship in preserving the cultural tradition of be'atan in children who will reach adulthood, then that is one of the offers in carrying out da'wah activities based on the Al-Qur'an and Hadith. At the same time, it becomes the basic material for someone who has a very important role in the process of that da'wah activity.

Research on Islamic $d a^{\prime} w a h$ values in local traditional activities has been carried out, including Jailani and Rachman (2020), which examines Islamic values in the most common traditions in Lumajang. This study concluded that there are Islamic values in the most common practices, among others, to foster a spirit of charity, strengthen brotherhood among Muslims, and maintain good habits in society. Setyaningsih (2020), who examines Javanese culture's acculturation as a $d a^{\prime}$ wah strategy, explains that Islam has entered and can be accepted by the community through local cultural propaganda. Meanwhile, Rahmaniar et al. (2020) found side by side between local culture and Islamic values. As in previous studies, this study examines the values of Islamic $d a^{\prime} w a h$ in local traditions, especially the values in Gorontalo society. 


\section{LITERATURE REVIEW}

The main objective of $d a^{\prime} w a h$ is the spread of Islam throughout the world, and Islamic teachings can be practiced in Muslim communities' daily lives. This noble goal cannot be achieved only through discourse in scientific forums but requires direct movement and practice from all Muslim community elements. What is practiced in the daily life of Muslims is an essential da'wah message. Muslims' tough task is how to transform Islamic teachings into teachings that can inspire and encourage people to have high awareness in practicing Islamic teachings. Actually, every Islamic teaching contains values for human life. It' is just that there is a gap between the theory taught and the practice that is done. Scholars have conveyed many things about Islamic teachings, both concerning faith, sharia, and morals, but it is sometimes far from Islamic teachings in practice. It is not an easy matter to change the tradition, but it is also not impossible for Muslims to achieve. Therefore, one of the efforts is to understand the importance of knowing the values contained behind the noble teachings of Islam.

The importance of understanding Muslims' values is because it is attached to the linkages between several humans who are bound as a consequence of social relations. The process of social relations is a process of interaction that contains certain values, both implicitly and explicitly, which are actually felt by the preacher or the object of $d a$ 'wah, who observes the process of $d a^{\prime} w a h$ activities. Value can be interpreted as a price. If it is related to culture, it means an abstract concept that is fundamental and valuable to human life (Dictionary Compilation Team of the Center for Language Development, 1993). According to Effendy (2003), values are views, ideals, customs, etcetera, that cause emotional responses to a particular person or society. Meanwhile, according to Fraenkel in Basit (2013), value is an idea or concept about something that is considered important. When someone judges something, that person considers the value important, useful, or valuable.

There are three crucial elements related to understanding value: value, the subject that gives value, and the object given the value. Subjects and objects cannot be separated. The value appears after an object is observed by the subject. It is the relationship between the subject and the object that gives rise to the concept of value. According to Anderson in Effendy (2003), value is a central component that guides and guides one's actions or activities. For example, someone who wants strength will connect his attitudes and activities with central values, such as special remembrance related to God's belief. That central value is the motivation to get this power. If this is related to $d a$ 'wah, it will be known as $d a$ 'wah's value, namely Islamic values that come from the al-Qur'an and Hadith. Da'wah values are not an inanimate object but rather dynamic values that are adjusted to the spirit of the times and the development of science in society. According to Sulthon (2003), Islamic values contained in the alQur'an are historical, dynamic, dialectical, and prophetic-transformative. The al-Qur'an values need to be in dialogue with the realities in society as the developer of the mandate on this earth. The al-Qur'an only has meaning for humans if it is embedded in human minds and is manifested in concrete actions. To make this happen, a preacher needs to internalize da'wah's values in himself so that the $d a^{\prime} w a h$ messages that will be conveyed will consider these values, and $d a^{\prime} w a h$ activities will run as expected.

This explanation is a concrete illustration of how $d a ' w a h$ activities cannot be separated from Islamic values that are tailored to the needs and understanding of the community who are the object of da'wah. Da'wah of Islam to Indonesia is complete with its arts and culture, so Islam cannot be separated from Arabic culture. At the beginning of Islam's 
development in Indonesia, it was felt so difficult to anticipate any differences between Islamic teachings and Arabic culture. The growth and development of Islam in Indonesia are processed in such a way by the preachers in various ways, both through language and culture, as was done by the Walisongo in Java. The Walisongo, with all their prowess, can apply Islamic teachings through the language and culture of the local area so that people can accidentally acquire Islamic values, which in turn can package and turn into customs in their life and daily life and directly become part of it, which is inseparable from the culture of the Indonesian nation. Many use Arabic every time traditional ceremonies are held, which has been directly entered into the regional language and Indonesia. It is not realized that what is being implemented is none other than the teachings of Islam.

Comprehensive Islamic teachings can also be witnessed in terms of carrying out Eid al-Fitr 1 Syawal, which was originally celebrated jointly and simultaneously by all Muslims wherever they are. However, what later developed in Indonesia was that all levels of society, regardless of or not seeing religion, jointly held Syawalan (halal bi halal) for one full month in the month of Shawwal. It is what is essentially derived from the values of Islamic teachings, namely realizing the bonds of brotherhood among friends using a friendship with one another. Comprehensive Islamic teachings can also be witnessed in terms of carrying out Eid al-Fitr 1 Syawal, which was originally celebrated jointly and simultaneously by all Muslims wherever they are. However, what later developed in Indonesia was that all levels of society, regardless of or not seeing religion, jointly held Syawalan (halal bi halal) for one full month in the month of Shawwal. It is essentially derived from the values of Islamic teachings, namely realizing the bonds of brotherhood among friends through friendship with one another.
Actions taken by Muslims should be built from a comprehensive understanding of Islamic teachings in which there are universal $d a$ 'wah values. Some universal $d a^{\prime} w a h$ values can be applied in the life of the people, including discipline, honesty, hard work, and cleanliness. Islam is a perfect religion and serves as a guide for all dimensions of human life, as Allah Almighty states in the al-Qur'an, Al-Maidah: 3 (Ministry of Religion of the Republic of Indonesia, 2007).

"On this day, I have perfected your religion for you, and I have provided for you my favor, and I have accepted that Islam is your religion".

The perfection of Islam as a guide for life is universalintegral, which transcends geographical and epochal boundaries. Islamic da'wah values are absolute, eternal, and valid for all time, apply to all cultures, and apply to all ethnic groups. Allah Almighty states this in the al-Qur'an, Al-Anbiya': 107, "and we did not send you, but to be a blessing for the universe."

The main reference in understanding $d a$ 'wah is the values of $d a$ 'wah taught by the Prophet Muhammad, whose capacity is uswatun hasanah, as well as an example of a figure who has a complete and qualified profile as well as unquestioned scientific capabilities. Thus, the prophet Muhammad became the founder of the theory of da'wah's concept in the development of knowledge related to the practice of $d a$ 'wah. The values of da'wah taught by the Prophet Muhammad, by Imam al-Ghazali, were explained through the theory of science by mentioning it in the book Ihya 'Ulumuddin that knowledge that is fardhu' ain knowledge that is obligatory for every Muslim so that he will avoid committing sins against Allah - there are two kinds. First, the science of mukasyafah, which is the knowledge that must be known only. Second, the knowledge of mu'amalah, which is the knowledge 
that must be known and practiced. According to alGhazali, the science of mukasyafah is too complicated, but it can be achieved by practicing mu'amalah knowledge. So, from these two sciences only mu'amalah knowledge can be practiced (Al-Ghazali, 2003).

Mu'amalah science includes three things. First, everything related to belief in the form of itiqad. Second, everything that must be done is an order. Third, everything that must be left is a prohibition (Al-Ghazali, 2003). These three things are the essence of the teachings of the Prophet Muhammad. Although the Koran and the Sunnah do not all speak directly about aqidah, orders, or prohibitions, they are always implicitly related to these three things. For example, when the al-Qur'an discusses the universe, it implicitly and explicitly describes Allah Almighty's belief as the sole owner and preserver of the universe. Likewise, when the al-Qur'an talks about the stories of people who were angry with Allah, there is a prohibition not to repeat these people's actions. Of the three, belief is the earliest and most important science because it is a belief that drives a person to do or leave an action. That is why, before someone is bound by Islamic law, he must start by declaring his faith (shahadat). Without faith, there is no obligation to carry out orders or leave prohibitions.

Prophet Muhammad SAW, who always received guidance from Allah Almighty in carrying out his $d a$ 'wah duties, was well aware that the key to change lies in the solidity of belief. Without faith, people will be confused and live without direction so that every step is always filled with doubts. In other words, this belief is the strength of every charity, and no charity is perfect unless it departs from a perfect belief. That is why in the early days of preaching, the Prophet SAW continuously fostered the aqidah of Muslims. This is consistent with the theme of the Makiyyah verses that were revealed in the first phase of $d a^{\prime} w a h$, namely when Muslims had not yet migrated to Madina, where most of the verses that came down were verses about aqidah or tawhid which discuss the obligation to only worship Allah, proof of the truth of the message of Prophet Muhammad SAW, the day of retribution, heaven and hell. Whereas in the second phase, which is after the hijrah, the Qur'anic verses tend to discuss more obligations and prohibitions such as matters of worship, muamalah, family, inheritance, jihad, and others (Al-Qattan, 2007).

\section{METHODS AND MATERIAL}

This research was field research. This type of research was descriptive qualitative, namely research that seeks to provide an overview of the phenomena and circumstances that occur and map the location based on the research object's scientific conditions (Ali, 2002). In this study, the researcher acted as a key instrument that directly conducts field research, interacts actively with data sources or informants to obtain objective data. In this study, the researcher collected several pieces of information needed relating to the research theme from several literature books and several sources whose position was the sample. Sugiyono (2008) states that informants, participants, or informants are samples in descriptive qualitative research. The sample in qualitative research is called the sample data source. The researcher determined the data sources purposively, namely the selected sources with specific considerations and goals. First, having intellectual competence and a deep understanding of the form of religious life in Gorontalo city. Second, having the ability to adapt to any changes in society related to diversity in religion. Third, these sources understand the implications of the diversity of life in religion.

In qualitative research, the researcher is the main instrument in extracting and exploring naturalistic data in the field. Other tools used are as follows. First, 
interview guidelines, namely a list of questions in conducting question and answer or direct dialogue with religious leaders, community leaders and traditional leaders, using a recording device in the form of a tape recorder. Second, using field notes in making observations, namely data collection, by making direct observations of objects related to the diversity of life in religion in the people of Gorontalo city. Third, documentation is data obtained in the field in documents related to the research topic. The instruments used were a tape recorder, camera, and field notes. Researchers collected data naturally through participant observation, in-depth interviews, documentation, and reference searches (Sugiyono, 2008). Existing data were analyzed qualitatively. Data processing took place simultaneously with the data collection process, through three stages: data reduction, data presentation, and data verification.

\section{RESULTS AND DISCUSSION}

Gorontalo is an area that has a lot of local cultures. Of the many cultures that exist, there must be certain goals and objectives. With this richness of cultural customs, Gorontalo has a philosophy of "custom based on shariah, and shariah based on the book of Allah (al-Qur'an)". It means that each Gorontalo custom refers to Islamic law, which is based on the Al-Qur'an When viewed carefully, all traditional processions contain $d a ' w a h$ values and are not just ordinary rituals. In be'atan tradition, for example, some punches are conveyed so that a deceitful woman gets provisions in carrying out the phases of her life to a higher level, such as being married. One of the traditional be'atan rituals that contain Islamic messages is the process of stepping on a plate containing dayo flowers. In this process, a sick woman steps her feet slowly and does not rush on the plates. When implemented in Islam, it is according to the hadith that states that "all hasty actions come from the devil" (Cono, 2015).
The ritual process of stepping on the plate contains the message that a woman must be careful in her steps and not hurry. Meanwhile, the dayo flower conveys that every footstep is swung to spread kindness and provide peace to others. In Islamic teachings, it is called "rahmatan lilalamin" "mercy for the universe". In this case also the dayo flower has aesthetic value so that anyone who looks at it feels happy and peaceful. The effect is immediately felt in the heart. Likewise, in the bathing procession, the purpose of bathing in the be'atan ritual is to purify and scent. It also has Islamic values because Allah Almighty loves people who are always pure and fragrant. In detail, it can be concluded that anything that has positive elements in it means that there are Islamic values as long as they do not contradict Islamic law and always rely on the Al-Quran arguments as-sunnah.

The Gorontalo tradition of be'atan is actually a manifestation of Islamic sharia in Gorontalo, doing it in a certain tradition, where men undergo circumcision and women undergo be'atan. In particular, the sound is marked by the first menstrual period, where there are certain sequences that are customarily performed. So, the da'wah values contained in the be'atan process are the whole; for example, the ontology, epistemology, and axiology are all Islamic values. If it is understood as the value of $d a^{\prime} w a h$ in the sense of broadcasting, then there are many practices in that custom that can be categorized as having $d a$ 'wah values. First, in the procession of inviting family, neighbors forty left, forty right, forty backward, and forty in the future, this is also understood by the people of Gorontalo as the meaning of neighbor, and that is what is invited. Second, the procession of be'atan is to guide the girls to say two sentences of shahadat. This is a big message, not only to those concerned but also to those present. On that occasion, people who carry out the be'atan explain the meaning of the two sentences of shahadat, then explain Islam's pillars and the pillars of faith. So, 
all those present listened to the explanation about shahadat, the pillars of Islam, and the pillars of faith. That is a big $d a^{\prime} w a h$, so it is obligatory to carry out a knack for girls. It is required not because of its customs or traditions, but it is required under Islamic law that an adult must be converted to Islam.

The issue of immortality is a measure of whether a person is in Islam. The sound for Gorontalo Muslims considers it something very sacred. If women are not good in character, the Gorontalo people say that they may not have been deviated. It is just that the values in the sound are no longer understood as they were original. So it is only considered abortion as a Gorontalo child; the important thing is to make an innocent. The implementation of the be'atan tradition in the early days was different. It was not the same as the beginning because that value determined the sacred. Like what value is upheld, the more sacred it is, the more that value is allowed to be, the less sacred it is. The people of Gorontalo, now, the important thing is to drop the obligation, the people see of Gorontalo that the child has been deceived, that is enough. Gorontalo people do not understand these values as well as possible. The value of $d a^{\prime} w a h$ is meaningless because the implementation of the traditions has changed from the beginning. When a girl was cut off in the early days, it was not easy for her to leave the house. If you leave the house, you have to cover your body with a sarong and only stick out your eyes to see the road so that people do not know who it is. In the procession of be'atan, the family always looks for people who are believed to be able to influence and have charisma because if one chooses, there is nothing.

Girls in the be'atan procession are taught prayers. When you see the first blood, there is a greeting that is read. When you want to take a shower, there is an intention to take a bath, be guided, write it down, then save it, and that is the values of $d a^{\prime} w a h$. So, internally to the children who are not true, while externally to those who attend the event. Money is trampled on in the ritual process of being evil, meaning that it is not enslaved by money. In terms of traditional symbols, that is the meaning desired by tradition. However, in practice in today's society, it is no longer like that. The people are afraid to leave the immoral tradition because they are afraid of talking or judging by people. Children who have not professed the law are haram to marry because they have not embraced Islam. The positive element in parents who carry out the cult tradition is hope or prayer for the family or parents, especially so that their children become pious, free from social laws, neighbor talk, and slander (Kango, 2015).

Every customary event in the be'atan tradition has $d a^{\prime}$ wah values. Yusuf (2015) explains that every symbol that is in every be'atan traditional process is needed as a condition of a customary process. If one of these symbols is lost or reduced, it will also reduce the meaning and values contained in the customary process that is carried out. The event of molungudu custom (steam bath with traditional ingredients) has the value of spiritual and spiritual self-cleansing da'wah. In a traditional ceremony with traditional ingredients consisting of seven kinds of potions, it is hoped that the girl will avoid seven types of characteristics that will fluctuate in her life. 1) Nenne'olo, obnoxious behavior. 2) Wetetolo, speaking out of place, or just speaking. 3) Kekengolo, acting busy action. 4) Kureketolo, acting, and talking inappropriately. 5) Pa'ingolo, likes to argue with parents. 6) Bulabolo, cutting people off by boasting. 7) Hutatingolo, which means speaking and acting harshly. This is in line with the commandment of alQura'an, Al-Nisaa: 36, "Worship Allah and do not associate Him with anything. And do good to both mothers of your fathers".

The event of momonto custom in the process of 
be'atan have the values of spiritual and mental selfpurification $d a$ 'wah as follows. 1) The sign of being foreheaded is a statement not to worship other than Allah. 2) The mark on the neck and lower throat is a statement that you will not eat unclean food. 3) The mark on the shoulders and curves of the hands and feet is a statement of not committing a disgraceful act. 4) For parents and family, it is a statement of responsibility for children's safety as a mandate from Allah Almighty (Tonkonoo, 2015). This value is in line with al-Qur'an, An-Nahal: 97.

\begin{abstract}
"Whoever does good deeds, whether male or female, is in a state of faith, then, in fact, we will reward them with a better reward than what they have done."
\end{abstract}

The event of momuhuto custom (bathing in flower water) has aqidah value to provide moral education that refers to the girl's personal life principles. This is expected so that the girl becomes a person who has a better personality. Parents hope that their daughter has a commendable character (graceful personality), friendliness and refinement of character, stability in Islamic law, firm principles, clear thinking, skilled in work, and has affection in the household after marriage. Bulowe has a value so that the daughter will be fragrant in eternity, both physically and mentally, as a servant who obeys Allah's commands. Seven pieces of yellow bamboo pots have a value to purify oneself from sins to gain glory in this world and in the hereafter. The breaking of a chicken egg has a value to warn the girl so that she looks after herself like keeping the egg above the horn. The size of a coconut as a seat has value, and it is hoped that it can benefit humans and can make everyone happy. alQur'an surah Al-An'am: 132 states, "and each person gets degrees (balanced) with what he does and your Lord is not careless from what they do".
The event of mopohuta'a to waiste custom has the value of aqidah prudence in every step. Seven plates mean the seven aspects of a girl's defense in her life. The first plate, which contains soil and po'otoheto plants, is symbolized by soil, and it is hoped that the girl will have the stand, faith, devotion to Allah. The second plate containing corn, it is hoped that the girl can maintain her chastity in adolescence until she has a household later. The third plate containing rice, it is hoped that the value of humility will be in the girl. The fourth plate contains tala'a ngala'a or money of various values, which it is hoped that the girl's life will save her money in the future. The fifth plate contains purring leaves (polohungo). It is hoped that she can avoid bad deeds and embarrassment to her family in the life of the girl. The sixth plate contains bakohati umonu (a fragrant scrub/powder), with the hope that she can organize herself from adolescence to marriage. The seventh plate containing bulewe has value maintaining the family's good name, both as a girl or married (Yahya, 2015).

The mome'ati customary event has aqidah value to strengthen Islamic teachings and aims to be a role model for others. The principles that need to be instilled in the person of the child guided by the priest are as follows: 1) Preceded by the recitation of two sentences of the creed by the priest and followed by the girl. 2) Saying the pillars of faith and pillars of Islam. 3) Teach you how to take a menstrual bath. 4) Guidance for the child about behavior, devotion to God, and parents.

\section{v. CONCLUSION}

Be'atan is a tradition that must be carried out by the people of Gorontalo and is something sacred. This is because to determine whether a woman is Islam or not, she must undergo a profanity process. The $d a$ 'wah values in the tradition of be'atan procession are saying two sentences of shahadat, maintaining the 
good name of parents, moral education, selfpurification, deepening religious teachings, and being pious children. In the process of be'atan, an imam explains the meaning of two sentences of shahadat, the pillars of Islam, the pillars of faith, and the prayer to purify oneself. Be'atan must be implemented for girls not because of their customs or traditions, but because of the Islamic law that a baligh person must be converted to Islam.

\section{REFERENCES}

[1]. Ali, M. S. (2002). Metodologi Penelitian Agama, Pendekatan Teori dan Praktek. Cetakan I. Jakarta: Raja Grafindo Persada.

[2]. Al-Baghdadiy, A. M. (No Year). Tafsir Khazîn Mussamma Lubâb Ta'wîl fi Ma'âni al-Tanzîl. Jilid III. Beirut-Libanon: Dar Fikr.

[3]. Al-Ghazali, I. (2003). Ihya Ulumuddin. Jlid 1. Translated by Zuhri, M., Muctar, M., \& Misbah, M. Semarang: Asy-Syifah.

[4]. Al-Qattan, M. K. (2007). Studi Ilmu-Ilmu alQur'an, cetakan ke-10. Translated by Mudzakir AS. Jakarta: Pustaka Litera AntarNusa.

[5]. Basit, A. (2013). Filsafat Dakwah. Jakarta: Rajawali Pers.

[6]. Cono, M. I. (2015). Personal Communication.

[7]. Dictionary Compilation Team of the Center for Language Development. (1993). Indonesia Dictionary. Jakarta: Balai Pustaka

[8]. Effendy, O. U. (2003). Ilmu, Teori dan Filsafat Komunikasi. Bandung: Citra Aditya Bakti.

[9]. Jailani, A. K. \& Rachman, R. F. (2020). Kajian Semiotik Budaya Masyarakat: Nilai Keislaman dan Tradisi Ter-ater di Lumajang. Muharrik: Journal Dakwah dan Sosial, 3(02), 125-137

[10]. Kango, A. (2015). Personal Communication.

[11]. Ministry of Religion of the Republic of Indonesia. (2007). Al-Qur'an dan Terjemahannya. Semarang: PT. Toha Karya Putra.
[12]. Muhaimin et al. (2005). Kawasan dan Wawasan Studi Islam. Cet. I. Rawamangun-Jakarta: Prenada Media.

[13]. Rahmaniar, F. S., Suyitno, Supana, \& Saddhono, K. (2020). Keselarasan Kearifan Lokal dengan Nilai Keislaman pada Tradisi Labuhan Gunung Kombang di Kabupaten Malang. Jurnal Smart Studi Masyarakat, Religi, dan Tradisi, 06(01), 113-125

[14]. Setyaningsih, R. (2020). Akulturasi Budaya Jawa sebagai Strategi Dakwah. Ri'ayah, 5(01), 73-82

[15]. Soenarjo et al. (No Year). Al-Qur'an dan Terjemahannya ke dalam Bahasa Indonesia. Riyadh-Saudi Arabiah: Kementerian Agama, Wakaf dan Dakwah Press.

[16]. Sugiyono. (2008). Memahami Penelitian Kualitatif. Cetakan IV. Bandung: Alfabeta.

[17]. Sulthon, M. (2003). Desain Ilmu Dakwah. Yogyakarta: Pustaka Pelajar dan Walisongo Press.

[18]. Tonkonoo, S. (2015). Personal Communication.

[19]. Yahya, A. (2015) Personal Communication

[20]. Yusuf, R. (2015). Personal Communication.

\section{Cite this article as :}

Pattaling, Said Subhan Posangi, Tita Rostitawati, "Islamic Da'wah Values of Be'atan Tradition in Gorontalo City, Indonesia", International Journal of Scientific Research in Science and Technology (IJSRST), Online ISSN : 2395-602X, Print ISSN : 23956011, Volume 8 Issue 1, pp. 42-50, January-February 2021. Available at doi : https://doi.org/10.32628/IJSRST21814 Journal URL : http://ijsrst.com/IJSRST21814 